\title{
各種醸造用酵母のオリゴ糖に 対する発酵特性
}

\author{
最近, 各地の研究機関やメーカーで優良酵母の開発が盛んに行われているが，新規な酵母であることを主張す \\ るためにはメルクマールが必要である。 \\ 本稿はオリコ糖の発酸性の違いから各種の協会酵母をそれぞれある程度特定できることを解説していただいた \\ あのである。オリゴ糖の多い清酒を䁔造する上で参考になることが多い。
}

稲橋正明・吉田 清

\section{1. は じめに}

醸造用酵母として広く使用されているきょらかい酵母 をはじめ, 各種醸造用酵母の特性・特徵を把握するとい らことは重要であり, 種々検討されている。

醇造物の糖類に対する酵母の発酵性の研究に関連し て, 特に清酒中の糖類は甘味, 濃淡に影響を与える重要 な成分であることからすでに多くの研究が行われてお り, グルコース $\left(\mathrm{G}_{1}\right)$, マルトース $\left(\mathrm{G}_{2}\right)$ 及び非発酵性オ リゴ糖といわれるイソマルトース $\left(\mathrm{iG}_{2}\right)$, イソマルトト リオース $\left(\mathrm{iG}_{3}\right)$ ，パノース $(\mathrm{P})$, コウジビオース $(\mathrm{K})$, ニゲロース $(\mathrm{N})$ が清酒に存在することが知られてい る1)。

市販清酒の糖組成の中でオリゴ糖の全糖に占める割合 が $12 \sim 25 \%$ 程度, 特に $\mathrm{iG}_{2}$ は清酒中 $0.5 \%$ 程度含ま れているが, $\mathrm{G}_{3}$ 以上の $\alpha-1,4$ 結合及び $\mathrm{G}_{2}$ 以上の $\alpha-$ 1,6 結合を含むオリゴ糖, また $\alpha-1,2,1,3$ 結合のオリ ゴ糖は通常の酵母では発酵し難いか, 全く発酵されない といわれている2,3。

$\mathrm{iG}_{2}$ に対する 6 号， 7 号清酒酵母による資化性, 発酵 性は麻生ら ${ }^{4}$ により,また $\mathrm{G}_{1}$ と $\mathrm{G}_{2}$ の混合糖類に対する NP 酵母による資化性は馬場ら ているが, 筆者らは, 各種醸造用酵母の菌株によるオリ ゴ糖発酵性の差異を比較検討するとともに, オリゴ糖含 量の高い清酒製造 ${ }^{6}$ にオリゴ糖非発酵性酵母の利用の可 能性を探るための基礎的実験を試みた。その結果につい て解説する。

\section{2. きょうかい酵母の TTC 染色性とその発} 酵性及び $\beta$-アラニン培地での生育性

最初に TTC 染色性とその糖に打ける発酵性及び $\beta-$ アラニン培地での生育性を比較することにより，きょう かい酵母を個々に識別することが可能であるか検討し た。

TTC 染色性は, 色素である $2,3,5$ トリフェニルテト ラゾリウムクロライドいわゆる TTCを用いてシャーレ 上に生育したコロニーに重層して，そのコロニーの色調 を見るものであり，この TTC 色素を還元してフォルマ ザンとなり赤く染色される。この還元作用はチトクロー ム系の酸化還元に関与するコハク酸脱水素酵素あるいは フラビン酵素によるものといわれている7。

きょらかい酵母をはじめ, 優良清酒酵母のコロニーは 赤く染色され, 野生清酒酵母はピンクに, 呼吸欠損酵母 は還元されず白色に染色される8)。

しかしながら，このことは TTC 培地の炭素源にグル コースを用いた場合であり, 最近の調査では野生酵母を 含めほとんどが赤に染色される。一方従来の TTC 培地 にグルコース以外の炭素源を用いて生育したコロニーに 同様に TTC 染色を行うと，第1表のように各酵母によ つて異った染色性を示す9”。こ幾つかの炭素源を用い た染色法で, ある程度の酵母の識別が可能となった。赤 色に染色される株はその時用いた炭素源を良く発酵し， ピンク〜白はその用いた炭素源の発酵が弱いか全く発酵 性がないといら特徵がある。このことから基質の炭素源 の種類によって, 酵母の還元力に影響を与えることが判 明した。

次に $\beta$-アラニン培地での生育性であるが, 培地の窒 
第1表 各種きょうかい酵母の TTC 染色性とその糖に 対する発酵能及び $\beta$-アラニン培地での生育性

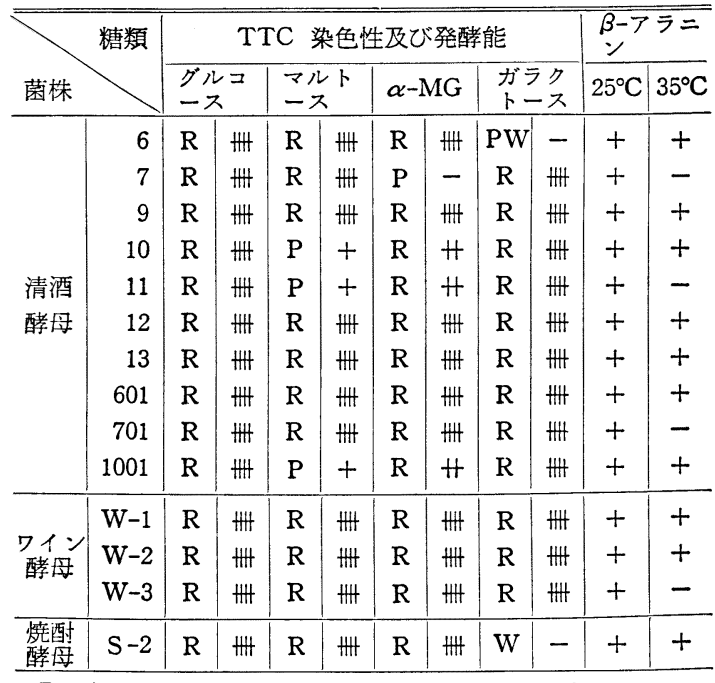

$\mathrm{R}:$ 赤色コロニー $\mathrm{P}:$ ピソクコロニー $\mathrm{W}:$ 白色コロニー $\mathrm{PW}$ : 白っぽいピンクコロニ $25^{\circ} \mathrm{C} て ゙ 3$ 日以内に発酵：州, 1 週間で:,+ 3 週間で $:+, \quad$-は 3 週間以上でも発酵し なかった。

素栄盖源に有機態窒素(例えばアミノ酸の一種であるア スパラギン, カザミノ酸等)を用いた場合, 大部分の清 酒酵母はパントテン酸を要求する。一方, 硫安などの無 機窒素源の培地では, 大部分の清酒酵母は要求がなくな る。しかしながら，きょらかい 7 号酵母をはじめ， 7 号 から分離した変異株であるアルコール耐性の 11 号, 7 号の变異株の泡なし 701 号は要求性を示し, この要求性 は高温 $\left(35^{\circ} \mathrm{C}\right)$ ほど戦しく, 低温 $\left(25^{\circ} \mathrm{C}\right.$ 以下) ではほと んどなくなる。ワイン酵母では W-3 号のみ要求性があ る。

以上のようなパントテン酸の要求性をシャーレ上で観 察するために，パントテン酸の代替効果のある $\beta$-アラ ニンを含む培地では 7 号などは $30 \sim 35^{\circ} \mathrm{C}$ の高温では生 育できない。これに対して，7号とその変異株以外の大 部分の酵母は高温でパントテン酸を含まない培地でも生 育できる。また, 7 号でも $25^{\circ} \mathrm{C}$ 以下の低温ではパント テン酸をほとんど要求しなくなり, 生育が可能となる10)。 この各種の TTC 染色性とその糖における発酵性及び $\beta$ アアラニン培地での生育性を比較することにより, ほと んどのきょらかい酵母を個々に識別することが可能とな った9)。

\section{例党ば,}

6 号酵母……ガラクトースを炭素源にした TTC 染色 性ではほとんど染色されず白っぽいピンクになる。

ガラクトース発酵性のないのはきょらかい酵母の中で 6 号酵母のみである。
7 号酵母……-.アラニン培地 $35^{\circ} \mathrm{C}$ での生育性がマイ ナスであり, マルトースを炭素源にした TTC 染色性が 赤で発酵性がある。

$\alpha$-メチル-D-グルコシド（以下 $\alpha-\mathrm{MG}$ ）を炭素源にし た TTC 染色性はピンクであり発酵性がない。

10 号酵母……マルトースを炭素源にした TTC 染色 性がピンクであり, マルトースの発酵性が微弱である。

7 号酵母と 701 号酵母…… $\beta$-アラニン培地 $35^{\circ} \mathrm{C}$ での 生育はマイナスで同じであるが, $\alpha-M G$ を炭素源にした TTC 染色性が 7 号はピンク 701 号は赤で識別可能であ る。

\section{3. マルトオリゴ糖に対する発酵特性 ${ }^{11)}$}

マルトオリゴ糖発酵性の差異による各醩母の識別が可 能であるかどらかを検討した。

\section{1）粉末水あめ中のマルトオリゴ糖に対する発酵能}

各種マルトオリゴ糖を含んでいる市販粉末水あめ $(\alpha-$ 1,4 結合のマルトオリゴ糖を主成分とし, 糖組成 $\mathrm{G}_{\mathbf{1}}$ $10.0 \%, \mathrm{G}_{2} 11.0 \%, \mathrm{G}_{3} 8.0 \%, \mathrm{G}_{4} 6.0 \%, \mathrm{G}_{5} 5.0 \%$, $\mathrm{G}_{6} 6.0 \%, \mathrm{G}_{7}$ 以上 $54 \%$ ) を使用し, YEPD 培地 (ポリ ペプトン $2.0 \%$ ，酵母エキス $1.0 \%$ ，グルコース $\left(\mathrm{G}_{1}\right)$ $2.0 \%)$ で $30{ }^{\circ} \mathrm{C} ， 3$ 日間前培養した各種醸造用酵母をポ リペプトン $1.0 \%$, 酵母エキス $0.6 \%$, 粉末水あめ $10 \%$ の培地に 1 白金耳接種し， $\mathrm{G}_{1}$ が消費されるのに 2 日間 を要するため, $25^{\circ} \mathrm{C}, 10$ 日間発酵させた後, 各マルトオ リゴ糖含量を高速液体クロマトグラフィー（HPLC）に よって測定した。なお，発酵能は各オリゴ糖を含む被験 培地を酵母により $25^{\circ} \mathrm{C}, 10$ 日間発酵させた時の糖の減 少率と定義した。

\section{2) $\mathbf{i G}_{2}$ 及び $\mathbf{i G}_{3}$ に対する発酵能}

$\mathrm{iG}_{2}$ 及び $\mathrm{iG}_{3}$ は粉末水あめ中には含まれていないので $\mathrm{G}_{1} 1.0 \%$, 東京化成製 ( 1 級) $\mathrm{iG}_{2}$ 及び $\mathrm{iG}_{3}$ 各 $1.0 \%$, ポリペプトン $1.0 \%$, 酵母エキス $0.6 \%$ の培地によって 試験した。

各種醇造用酵母による粉末水あめ中のマルトオリゴ糖 発酵能を第 2 表に, 試験培地の桾組成クロマトグラムを 第 1 目に, $\mathrm{iG}_{2}$ 及び $\mathrm{iG}_{3}$ 発酵能を第 3 表に示し, 各菌株 の $\mathrm{G}_{2}, \mathrm{G}_{3}, \mathrm{iG}_{2}, \mathrm{iG}_{3}$ 亿対する発酵能を分類すると以下 のようになった。 $\mathrm{G}_{1}$ はすべての株がよく発酵するので 省略した。

(1)いずれのオリゴ糖をも良く発酵する株……6 号, 9 号, 12 号, 601 号, 701 号, 901 号, NJK 6208, 6209, W-2 及び NJK 6413。

(2) $\mathrm{G}_{2}, \mathrm{G}_{3}$ のみを良く発酵する株..........

(3) $\mathrm{G}_{2}, \mathrm{iG}_{3}$ のみを良く発酵する株……7 7 号, 10 号。

(4) $\mathrm{G}_{2}$ のみを良く発酵する株……S -2 , NJK 6404, 
第 2 表 各種酾造用酵母による粉末水あめ中のマル トオリゴ桾に対する発酵性

\begin{tabular}{|c|c|c|c|c|}
\hline \multicolumn{2}{|c|}{$\begin{array}{ll}\text { 菌株 糖 } \\
\end{array}$} & マルトース & $\begin{array}{l}\text { マルトトリ } \\
\text { オース }\end{array}$ & $\begin{array}{l}\text { マルトテト } \\
\text { ラオース }\end{array}$ \\
\hline \multirow{11}{*}{ 清酒酵母 } & 6 & 0 & 45 & 100 \\
\hline & 7 & 0 & 99 & 100 \\
\hline & 9 & 0 & 14 & 100 \\
\hline & 10 & 65 & 100 & 100 \\
\hline & 11 & 93 & 100 & 100 \\
\hline & 12 & 0 & 14 & 100 \\
\hline & 13 & 50 & 100 & 100 \\
\hline & 601 & 0 & 58 & 100 \\
\hline & 701 & 0 & 19 & 100 \\
\hline & 901 & 0 & 14 & 100 \\
\hline & 1001 & 98 & 100 & 100 \\
\hline \multirow{3}{*}{ ワイン酵母 } & $\mathrm{W}-1$ & 0 & 0 & 100 \\
\hline & $\mathrm{W}-2$ & 0 & 59 & 100 \\
\hline & $\mathrm{W}-3$ & 0 & 82 & 100 \\
\hline \multirow{5}{*}{ 焼酎酵母 } & $S-2$ & 0 & 100 & 100 \\
\hline & 6404 & 0 & 98 & 100 \\
\hline & 6409 & 0 & 94 & 100 \\
\hline & 6410 & 12 & 100 & 100 \\
\hline & 6413 & 0 & 67 & 100 \\
\hline \multirow{2}{*}{ ビール酵母 } & 6208 & 0 & 0 & 78 \\
\hline & 6209 & 0 & 0 & 84 \\
\hline
\end{tabular}

*おおおのの值は被験培地を酵母により $25^{\circ} \mathrm{C}, 10$ 日間発酵さ せた時の糖の残存率を示す。

グルコースの残存率 : 0\%

マルトペンタオース以上は発酵しない。

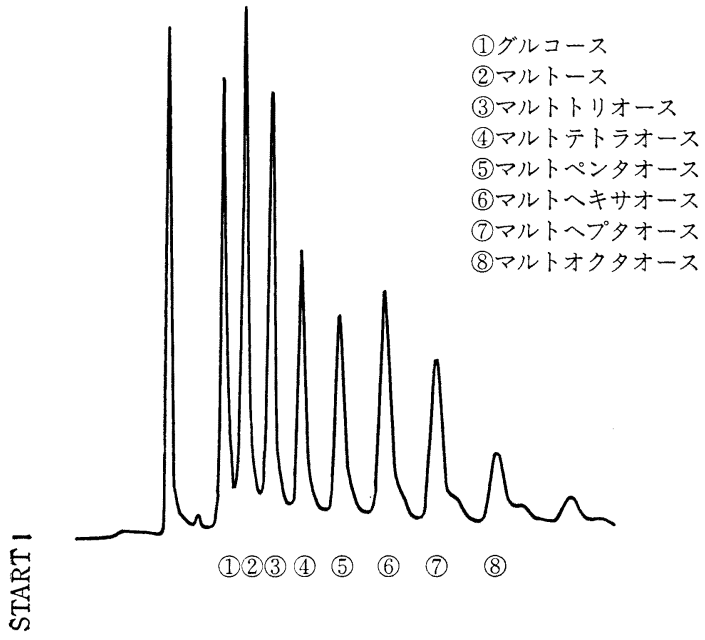

第1図 試験培地の糖組成クロマトグラム

6409，及び NJK 6410。

(5) $\mathrm{iG}_{2}$ を良く発酵するが， $\mathrm{G}_{2}, \mathrm{G}_{3}, \mathrm{iG}_{3}$ の発酵能が非 常に弱いか全く発酵しない株......11 号, 1001 号。

(6) $\mathrm{G}_{2}, \quad \mathrm{iG}_{2}, \quad \mathrm{iG}_{3}$ を良く発酵するが, $\mathrm{G}_{3}$ の発酵能の非
第 3 表 各種醉造用酵母によるイソマルトース及 びイソマルトリオースに対する発酵性

\begin{tabular}{|c|c|c|c|}
\hline \multicolumn{2}{|c|}{\begin{tabular}{|ll} 
菌校 糖 \\
\end{tabular}} & イソマルトース & $\begin{array}{l}\text { イソマルトトリ } \\
\text { オース }\end{array}$ \\
\hline \multirow{11}{*}{ 清酒酵母 } & 6 & 0 & 43 \\
\hline & 7 & 32 & 84 \\
\hline & 9 & 0 & 18 \\
\hline & 10 & 25 & 92 \\
\hline & 11 & 28 & 96 \\
\hline & 12 & 0 & 15 \\
\hline & 13 & 19 & 38 \\
\hline & 601 & 0 & 58 \\
\hline & 701 & 0 & 15 \\
\hline & 901 & 0 & 18 \\
\hline & 1001 & 21 & 96 \\
\hline \multirow{3}{*}{ ワイン酵母 } & $\mathrm{W}-1$ & 73 & 100 \\
\hline & $\mathrm{W}-2$ & 0 & 60 \\
\hline & W-3 & 0 & 24 \\
\hline \multirow{5}{*}{ 焼酎酵丹 } & $S-2$ & 89 & 100 \\
\hline & 6404 & 90 & 100 \\
\hline & 6409 & 88 & 100 \\
\hline & 6410 & 92 & 100 \\
\hline & 6413 & 0 & 20 \\
\hline \multirow{2}{*}{ ビール酵母 } & 6208 & 10 & 15 \\
\hline & 6209 & 0 & 10 \\
\hline
\end{tabular}

* おのおのの值は被験培地を酵母により $25^{\circ} \mathrm{C}, 10$ 日間 発酵させた時の糖の残存率を示す。

グルコースの残存率 : $0 \%$

常に弱い株……13 号, W-3 号。

このタイプは $\mathrm{G}_{3}$ 発醅能が弱いのに $\mathrm{iG}_{2}$ 及び $\mathrm{iG}_{3}$ の 分岐状オりゴ糖を良く発酵する酵母であり, 醸造用酵母 としては特異な発酵性を示している。

このように酵母によっては, 従来非発酵性糖といわれ るものでも良く発酵するものもあり，乙かしながら発酵 性の弱い酵母は, $\mathrm{G}_{1}$ が存在しなくても発酵能は弱かっ た。

また親株と泡なし株において， 7 号と 701 号の $\mathrm{G}_{3}$ 発 酵能, 10 号と 1001 号の $\mathrm{G}_{2}$ 発酵能に違いが認められた が, 7 号と 701 号では, ある種の糖の発醭性 (701 号は $\alpha-\mathrm{MG}$ を良く発酵するが， 7 号は発酵しない）が異なる ことが分かっており ${ }^{12)}, \mathrm{G}_{3}$ の発醅性の違いもこれらに関 連しているかどうか現在検討中である。また，10 号と 1001 号の $\mathrm{G}_{2}$ 発酵能の違いについては, 6 号と 601 号 の $\mathrm{G}_{3}$ 発酵能（発酵能に大差ない）を含めて今後の検討 課題である。

13 号は 9 号と 10 号の交配種であり, $\mathrm{G}_{2}$ の発酵能で はどちらかといらと 10 号の特徴を示した。

ワイン酵母の W-2 号は 6 号と W-1 号の交配種であ り, $\mathrm{G}_{3}$ の発酵能に括いては, 6 号の特徽をよく示して いた。 


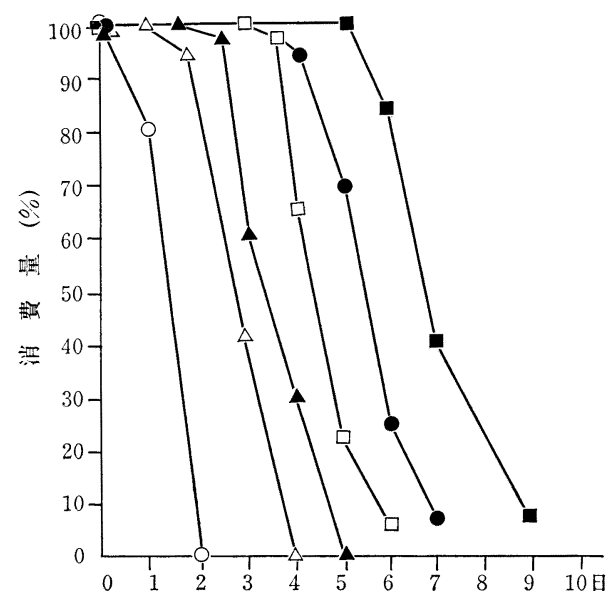

第 2 図きょらかい 9 号酵母による各オリゴ糖の消 費変化

$$
\begin{aligned}
& \text { ーーーグルコース - ーーマルトース 一ローマルトト } \\
& \text { リオース ー・ーパノース ームーイソマルトース } \\
& \text { 一ローイソマルトトリオース }
\end{aligned}
$$

\section{3）酵母による各オリゴ糖の消費順序}

酵母による各オリゴ糖の消費される順序を調べるため 飞 $\mathrm{G}_{1}, \mathrm{G}_{2}, \mathrm{G}_{3}, \mathrm{iG}_{2}, \mathrm{iG}_{3}$, 及びP各 $1.0 \%$, ポリペプト ン $1.0 \%$ ，酵母エキス $0.6 \%$ の培地を調製し試験した。 数種類のオリゴ糖を良く発酵する菌株のうち, 現在広 く使用されている 9 号について各オリゴ糖の消費される 順序を調べた結果を示した(第 2 図)。 $\mathrm{G}_{1}($ が1\%)の培地 そおいて，発醭特性を調べたところ $\mathrm{G}_{1}$ が約 $80 \%$ 消費 されると次注 $\mathrm{G}_{2}, \mathrm{iG}_{2}$ の順で徐々に消費された。また $\mathrm{G}_{2}, \mathrm{iG}_{2}$ が約 $50 \%$ 消費されると $\mathrm{G}_{3}$ が徐々に消費され， さらに $\mathrm{P}, \mathrm{iG}_{3}$ の順に消費されることが明らかになっ た。

以上, 酵母の粉末水あめ中のマルトオリゴ糖の発酵性 や $\mathrm{iG}_{2}, \mathrm{iG}_{3}$ の発酵性を比較することにより醸造用酵母 の各オリゴ糖に対する発酵特性をとらえることができた ものと考える。

\section{4. $\mathrm{iG}_{2}$ 及び $\mathrm{iG}_{3}$ 発酵能の異なるきょう かい 7 号酵母の一般的諸性質と䁔造 特性}

各種釀造用酵母のマルトオリゴ糖の発酵性を調べた結 果では，それぞれの酵母の $\mathrm{G}_{2}, \mathrm{iG}_{2}$ 及び $\mathrm{iG}_{3}$ などの発 酵性に顕著な違いがあったので， $\mathrm{iG}_{2}$ 及び $\mathrm{iG}_{3}$ などの才 リゴ糖含量の異なる清酒を得る目的できょらかい酵母よ り $\mathrm{iG}_{2}$ 及び $\mathrm{iG}_{3}$ 発酵能の異なる酵母を分離し，一般的 諸性質及び醸造特性について比較検討を試みた。

\section{1) $\mathrm{iG}_{2}$ 及び $\mathrm{iG}_{3}$ 発醥能の異なる酵母の分離}

前述の TTC 培地の炭素源として用いる糖類を変える ことにより既存の醸造用酵母より糖の発酵性の異なるコ

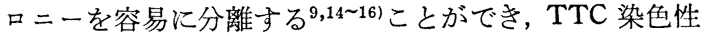
に抢いて赤媣色される酵母はその糖を良く発酵し，ピ ンクあるいは白に染色される酵母はその糖の発酵性が弱 いか，発酵しな(18,12) といらことを利用して $\mathrm{iG}_{2}$ 及び $\mathrm{i}_{3}$ 発酵能の異なる酵母を取得することを試みたとこ ろ, 7 号より $\mathrm{iG}_{2}$ 及び $\mathrm{iG}_{3}$ 培地での $\mathrm{TTC}$ 染色性が赤 およびピンクに染色される株が一定の割合で出現し，そ の赤 ( $\mathrm{R}$ 株) とピンク（ $\mathrm{P}$ 株）飞染色される株を分離し た。

筆者ら はすでに 7 号酵母から炭素源に $\mathrm{G}_{2}$ を用いた TTC 染色法により染色性の異なる株を分離しているが, $\mathrm{iG}_{2}$ 及び $\mathrm{iG}_{3}$ を用いた場合でも同じように TTC 染色性 の異なるコロニーが出現した。

\section{2）一般的諸性質}

分離菌の $\mathrm{R}$ 及び $\mathrm{P}$ 株それぞれの一般的性質のうち， $\mathrm{R}$ 及び $\mathrm{P}$ 株間で対照的な性質を示したものを掲げた（第 4 表)。 $\mathrm{iG}_{2}$ 及び $\mathrm{iG}_{3}$ 培地に打いて $\mathrm{R}$ 株は $\mathrm{iG}_{2}, \mathrm{iG}_{3}$ 発酵能 が強く, 一方 $\mathrm{P}$ 株は $\mathrm{iG}_{2}, \mathrm{iG}_{3}$ の発酵能が弱かった。 $\beta$ アラニン培地での増殖性は $\mathrm{R}, \mathrm{P}$ 株共に親株の 7 号と同 じ性質を示した。 $\mathrm{G}_{2}$ 培地及び $\alpha-\mathrm{MG}$ 培地での TTC 染 色性及び発酵能については $\mathrm{R}$ 株，P株はそれぞれ異なっ た染色性と発酵能を示したが， 7 号の特徵である ${ }^{12)} \mathrm{G}_{2}$ 培地での TTC-Red 株は $\alpha-\mathrm{MG}$ TTC 染色性がピンク

\begin{tabular}{|c|c|c|c|c|c|}
\hline \multirow{2}{*}{\multicolumn{2}{|c|}{$\begin{array}{l}\text { 分析項目 } \\
\text { イソマ菌株 } \\
\text { TTC 及びー発酵 } \\
\text { 能 }\end{array}$}} & \multicolumn{2}{|c|}{ A } & \multicolumn{2}{|c|}{ B } \\
\hline & & $\mathrm{R}$ & HI & $\mathbf{P}$ & + \\
\hline \multicolumn{2}{|c|}{$\begin{array}{l}\text { イソマルトトリ } \\
\text { オースTTC 及 } \\
\text { び発酵能 }\end{array}$} & $\mathrm{R}$ & HI & $\mathrm{P}$ & + \\
\hline \multicolumn{2}{|c|}{$\begin{array}{l}\text { マルトースTTC } \\
\text { 及び発酵能 }\end{array}$} & $\mathrm{P}$ & - & $\mathrm{R}$ & 曲 \\
\hline \multicolumn{2}{|c|}{$\begin{array}{l}\alpha-M G \text { TTC } \\
\text { 及び発酵能 }\end{array}$} & $\mathrm{R}$ & HI & $\mathrm{P}$ & - \\
\hline \multicolumn{2}{|c|}{$\begin{array}{l}\text { ガラクトース } \\
\text { TTC 及び発酵 } \\
\text { 能 }\end{array}$} & $\mathrm{R}$ & HI & $\mathrm{R}$ & 冊 \\
\hline $\begin{array}{l}\beta \text {-アラ } \\
\text { ニン }\end{array}$ & $\begin{array}{l}25^{\circ} \mathrm{C} \\
35^{\circ} \mathrm{C}\end{array}$ & \multicolumn{2}{|c|}{+} & \multicolumn{2}{|c|}{+} \\
\hline \multicolumn{2}{|c|}{ 堭大コロニー形 } & \multicolumn{2}{|c|}{ 平坦 } & \multicolumn{2}{|c|}{ しわ・ひだ } \\
\hline
\end{tabular}
になり，一方 $\mathrm{G}_{2}$ 培地での TTC-Pink 株は $\alpha$-MG TTC

第 4 表 一般的諸性質

$\mathrm{R}:$ 赤色コロニー $\mathrm{P}:$ ピンクコロニー $25^{\circ} \mathrm{C}$ で 3 日以内に発酵：卅，3 週間で :,+ -は 3 週間以上 でも発酵しなかった。

$\mathrm{A} ：$ イマルトース, イソマルトトリオース TTC 赤

B : " " TTCピンク 
第5表 一 般 分 析

\begin{tabular}{|c|c|c|}
\hline 分析項目 菌 株 & A & B \\
\hline 日本酒度 & -6.0 & -5.5 \\
\hline アルュール分 $(\%)$ & 18.0 & 18.0 \\
\hline 総 酸 度 & 2.85 & 3.30 \\
\hline アミノ酸度 & 1.90 & 2.00 \\
\hline 色度 $\mathrm{OD}_{30}^{43}{ }^{\prime}$ & 0.104 & 0.109 \\
\hline イソアミルアルュール（ppm） & 210 & 215 \\
\hline 酢酸イソアミル（ppm） & 5.4 & 4.8 \\
\hline$(E / A) \times 100$ & 2.6 & 2.2 \\
\hline リンゴ酸（ppm） & 334.8 & 526.1 \\
\hline コハク酸 & 509.8 & 510.2 \\
\hline 酢酸（ppm） & 48.6 & 48.0 \\
\hline グルコース $(\%)$ & 2.04 & 2.10 \\
\hline イソマルトース (\%) & 0.53 & 0.55 \\
\hline イソマルトトリオース（\%) & 0.35 & 0.37 \\
\hline
\end{tabular}

総米 $150 \mathrm{~kg}$ 仕込及

$\mathrm{A} ：$ インルトース，イソマルトトリオース TTC 赤

B : " " TTC ピソク

染色性が赤になるといら性質は変わらなかった。

また， $\alpha-\mathrm{MG}$ 及び $\mathrm{iG}_{2}$ の発酵㳊関与する酵素系はか なり似かよったものであることを照井ら ${ }^{17) に よ っ て す ~}$ でに報告されているが，TTC 試験において $\alpha-\mathrm{MG}$ 培地 での TTC 染色性と $\mathrm{iG}_{2}$ 培地でのそれとは両株とも同じ 染色性を示し, この結果は酵素系がかなり似ているとい ら前記照井ら开の報告を裏付けるものとい方よう。さら に, $\mathrm{iG}_{3}$ 培地での TTC 染色性と $\alpha-\mathrm{MG}$ TTC 染色性に おいても同じ染色性を示すが，iG 系の糖のすべてが $\alpha$ MG と同じ TTC 染色性を示すかどうかは将来の興味あ る課題である。

\section{3）仕込試験}

分離した $\mathrm{R}$ 株及び $\mathrm{P}$ 株を用いて, 総米 $150 \mathrm{~kg}$ の清酒 仕込を行い, その結果を示した (第 5 表)。 $\mathrm{R}$ 株, P 株共 日本酒度, アルュール分, アミノ酸度, 色度及び $\mathrm{G}_{1}$ 濃 度,さらに表には示さなかったがアミノ酸組成にはいず れも差が認められなかった。熟成醪中の酵母の $\mathrm{iG}_{2}$ 培地 及び $\mathrm{iG}_{3}$ 培地での $\mathrm{TTC}$ 染色を行ったが， $\mathrm{R}$ 株， $\mathrm{P}$ 株共 に染色性には変化はなかった。また， $\mathrm{R}$ 株， $\mathrm{P}$ 株の製成 酒の $\mathrm{iG}_{2}$ 及び $\mathrm{iG}_{3}$ 含量については両株に差が認められ なかった。 $\mathrm{iG}_{2}, \mathrm{iG}_{3}$ を分解する酵素は, $\mathrm{G}_{2}$ 分解酵素 （マルターゼ）と同様唀導酵素々思われ，醪中の $\mathrm{iG}_{2}$, $\mathrm{iG}_{3}$ の変化之酵素の働きについては将来検討が必要であ ろらと考皇た。

$\mathrm{R}$ 株， $\mathrm{P}$ 株の酸度を比較してみると， $\mathrm{P}$ 株の方が酸度 が高い傾向が認められた。 $\mathrm{G}_{1}$ 培地での TTC 染色性が ピンクの株は，酢酸、リンゴ酸などが多くなり，酸度が 高くなるという報告81はすでにあるが， $\mathrm{P}$ 株は， $\mathrm{G}_{1}$ 培地 での TTC 染色性赤であるにもかかわらず酸度が高くな

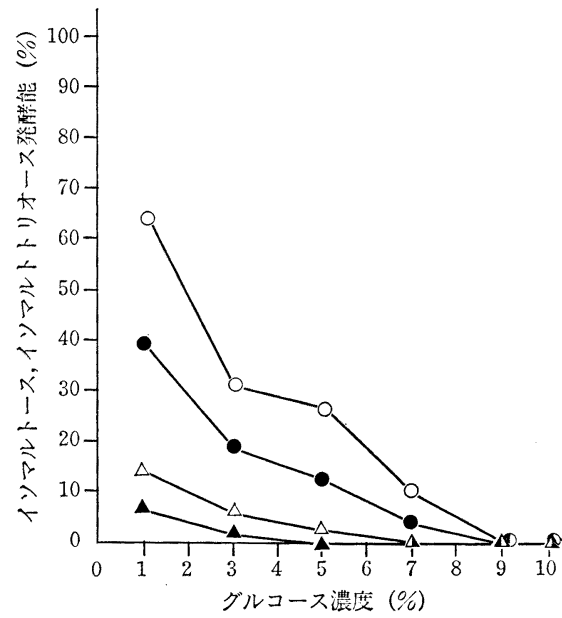

第3図 グルュース濃度の異なる粷汁培地 でのイソマルトース及びィソマルト トリオース発酵能の違い

初発のイソマルトース及びイソマルトトリオース 濃度 : $0.5 \%$

ー○ーイソマルトース TTC 赤

一・ イソマルトース TTC ピンク

一ーー イソマルトトリオース TTC 赤

ームーイソマルトトリオース TTC ピンク

った。 $\mathrm{R}$ 株と $\mathrm{P}$ 株の酸度の差は, リンゴ酸含量の違いに よるものであり, 酰酸及び他の有機酸含量には差が認め られなかった。香気成分のらちイソアミルアルコール， カプロン酸エチル含量は, 両株間に差は認められなかっ たが，酢酸イソアミル含量及び $\mathrm{E} / \mathrm{A}$ 比においてはR株 が若干高いといら結果を得た。

4） $\mathrm{G}_{1}$ 濃度を変えた窲汁培地での $\mathrm{iG}_{2}$ 及び $\mathrm{iG}_{3}$ 発酵 能の違い

仕込試験において, 製成酒の $\mathrm{iG}_{2}$ 及び $\mathrm{iG}_{3}$ 含量には 両株間に差が認められなかったが, その理由として清酒 醪中の $\mathrm{G}_{1}$ 濃度が影響していると思われるので培地の $\mathrm{G}_{1}$ 濃度と $\mathrm{iG}_{2}$ 及び $\mathrm{iG}_{3}$ の発酵性を調べるため清酒製造 において最も近いと思われる数汁培地を用い，培地中の $\mathrm{G}_{1}$ 濃度を $2 ， 4 ， 6 ， 8$ 及び $9 \%$ になるように調整し， さらに $\mathrm{iG}_{2}$ 及び $\mathrm{iG}_{3}$ をそれぞれ $0.5 \%$ 添加した培地に おける $\mathrm{iG}_{2}$ 及び $\mathrm{iG}_{3}$ の発酵能を調べた結果を示した（第 3 図)。P株は培地中に $\mathrm{G}_{1}$ が $1 \%$ しか存在していない 時でも $\mathrm{iG}_{2}$ 及び $\mathrm{iG}_{3}$ 発酵能が弱く, $\mathrm{G}_{1}$ が $\mathrm{iG}_{2}$ 共存て は 7\%, $\mathrm{iG}_{3}$ では 5\% 以上になるとほとんど $\mathrm{iG}_{2}$ 及び $\mathrm{iG}_{3}$ を発酵しなくなった。一方, $\mathrm{R}$ 株は $\mathrm{iG}_{2}$ 及び $\mathrm{iG}_{3}$ 発 酵能が強く, 培地中の $\mathrm{G}_{1}$ 濃度が $7 \%$ であっても $\mathrm{iG}_{2}$ 及び $\mathrm{iG}_{3}$ を良く発酵した。以上のようにR株， $\mathrm{P}$ 株の $\mathrm{iG}_{2}$ 及び $\mathrm{iG}_{3}$ に対する発酵性の差は顕著であった。しか し両株共, $\mathrm{G}_{1}$ 濃度が $9 \%$ になると $\mathrm{iG}_{2}, \mathrm{iG}_{3}$ を発酵し 
なくなった。この現象は Wickerham と YP（酵母ェキ ス $0.6 \%$ ，ペプトン $1.0 \%$ ）の両合成培地を用いた試験 でも同様の結果が得られた。以上の結果より清酒酸では $\mathrm{G}_{1}$ 濃度が高いために $\mathrm{G}_{1}$ 発酵にとどまり, $\mathrm{iG}_{2}$ 及び $\mathrm{iG}_{3}$ 発酵にまで及ばない。よって製成酒中の $\mathrm{iG}_{2}$ 及び $\mathrm{iG}_{3}$ 含 量に差が生じなかったものと推察した。

\section{5. おわりに}

最初に述べたように各種醸造用酵母の特性・特徵をと らえるということは重要なことであり，本稿は筆者らが 行ってきた TTC 染色性とその糖における発酵性及び酵 母のマルトオリゴ糖の発酵性の差異による各種醸造用酵 母の識別, またマルトオリゴ糖の異なる酵母による仕込 試験の結果について解説したものであり，これらの結果 は, 各種醸造用酵母の各オリゴ糖に対する発酵特性をと らえることができたとともに，酒類を製造する際に酵 母, 翏の酵母の純度確認に大いに役立つもの之考觉る。 マルトオリゴ糖の異なる酵母の仕込試験ではオリゴ糖含 量の異なる清酒を得るという目的で行なった実験であり, 実際には醸造特性に差がないといら結論を得た。このこ とは, 酵母のオリゴ糖に対する発酵特性に違いがあって も, 実際の醸造ではもろみ中のグルコース濃度の過㮃等 によりその特性が表われないということが明らかになっ た。

最後に, 本研究を遂行の上で, ご指導, ご鞭撻を頂い た当会村上英也前会長, 野白喜久雄会長並びに中村常務 をはじめとする関係各位に深く感謝申し上げます。

( $<$ 財 $>$ 日本醸造協会)

\section{文献}

1）日本醸造協会：醸造成分一覧，p.8（1977）

2）麻生 清, 柴崎一雄, 山内文男 : 醱工， 32，47 (1954)

3）小林昭一, 貝沼圭二 : 醸協, 77,（9）581 (1982)

4) 麻生 清, 柴崎一雄, 卜部紫朗 : 醴工, 31,81 (1954)

5）馬場 茂, 小栗 勇, 福沢幹夫, 森山敬子, 飯田 俊彦, 小林 嚴, 今井謹也：醸協，69，（7）453 (1974)

6) 布川弥太郎 : 激粉科学, 28, (2) 109 (1981)

7) 古川敏郎，秋山裕一：農化，37，398 (1963)

8) 秋山裕一：改訂清酒酵母の研究（清酒酵母研究会 編), p. 188, 清酒酵母研究会 (1980)

9）村上英也, 吉田 清, 野呂二三, 稲橋正明, 服部 裕子：醸協, 77, （3）181（1982）

10）菅間誠之助, 山川浩一郎, 潟岡嚴一, 山村紘司, 野白喜久雄：䣯協，66，（5）453(1965)

11）稲橋正明, 吉田 清, 中村欽一：醸協，87，（4） 312 (1992)

12）吉田 清, 野呂二三, 稲橋正明, 村上英也 : 䂅協, 77 , (6) 413 (1982)

13）稲橋正明, 吉田 清, 中村欽一：䁔協，87，（5） 391 (1992)

14）吉田 清, 村上英也 : 醇協, 73，（3）218（1978）

15）山木 康, 井上喬： Rep. Kirin Brew Co., No. 5 , p. 11 (1962)

16）大内弘造, 布川弥太郎：醅協，67，（5）462 (1972)

17）照井堯造，岡田弘輔，大沜泰治 : 醱工， $37 ， 177$ (1959) 